спрямованого змісту, пошук сучасних методів, прийомів та форм навчання, що сприяють становленню ключових та професійних компетентностей майбутніх фахівців, створення спеціальних навчальних посібників для студентів певної спеціальності є перспективними практичними завданнями викладачів вищої школи.

Отже, якщо вивчення математичної логіки ведеться з урахуванням принципу професійної спрямованості, то студенти бачать роль та значення дисципліни у своєму професійному становленні, зростає вмотивованість вивчення як окремих тем, так і всієї дисципліни, зацікавленість предметом, що сприяє досягненню кінцевої мети - становленню компетентного фахівця.

\title{
Література
}

1. Касаткін В. Крок за кроком за ЕОМ / Валентин Касаткін. - К. : Веселка, 1979. - 160 с.

2. Тіхонцова Н. I. Математична освіта студентів у світлі впровадження компетентністного підходу / Н. I. Тіхонцова // Матеріали всеукр. наук.-практ. конф. «Методологічні та методичні основи активізації навчально-пізнавальної діяльності студентів у процесі вивчення математичних дисциплін» ; 23-24 листопада 2009 р. - Ялта : РВВ КГУ, 2009. - Вип. 3. - С. 252-256.

3. Энциклопедия для детей. Т.11. Математика. - М. : Аванта +, 2004. - 688 с.

4. Якухно I.I. Компетентнісний підхід - шлях до Свропейської якості освіти / I.I. Якухно // Матеріали Міжнар. наук.-практ. конф. «Компетентністно орієнтована освіта: досвід, проблеми, перспективи» ; 5-6 листопада 2008 р. - Донецьк: Каштан, 2008. - С.54-59.

Стаття надійшла до редакції 30.04.2012 р.

УДК 373. 21: 172.3

К. О. Романюк, аспірант,

Прикарпатський національний університет ім. В. Стефаника

\section{ФОРМУВАННЯ ГОТОВНОСТІ ПЕДАГОГІВ ДНЗ ДО ВИХОВАННЯ МІЖЕТНІЧНОЇ ТОЛЕРАНТНОСТІ ДІТЕЙ (ЗА РЕЗУЛЬТАТАМИ ЕКСПЕРИМЕНТАЛЬНОГО ДОСЛІДЖЕННЯ)}

\footnotetext{
Романюк К.О. Формування готовності педагогів ДНЗ до виховання міжетнічної толерантності дітей (за результатами експериментального дослідження).

У статті автор визначає проблему формування міжетнічної толерантності як одну з актуальних в сучасній педагогічній науці. На основі опрачювання результатів експериментального дослідження визначено рівень готовності педагога та його роль у прочесі виховання міжетнічної толерантності дітей стариого дошкільного віку, зміст його діяльності в контексті окресленої проблеми, а також виокремлено шляхи підвищення фахового рівня педагогів.

Ключові слова: міжетнічна толерантність, навчально-виховний прочес, базова програма, компетентність.

Романюк К. А. Формирование готовности педагогов детского учебного учреждения $к$ воспитанию толерантности детей (по результатам экспериментального исследования).

В статье автор определяет проблему формирования межэтнической толерантности как одну из актуальных в современной педагогической науке. Анализ результатов экспериментального исследования позволил определить уровень готовности педагога и его роль в процессе воспитания межэтнической толерантности детей старшего дошкольного возраста, содержание его деятельности в контексте данной проблемы, а также пути повымения профессионального уровня педагогов.
} 
Ключевые слова: межэтническая толерантность, учебно-воспитательный прочесс, базовая программа, компетентность.

Romaniuk K. Formation of children's school readiness of teachers to the establishment of tolerance education of children (according to the results of the pilot study).

The article defines the problem of forming inter-ethnic tolerance as one of the current in modern pedagogical science. The results of experimental research allowed to determine teachers readiness and their role in process of forming inter-ethnic tolerance of preschool age children. We also determined the content of pedagogical activity and the ways of advanced training future pedagogues.

Key words: inter-ethnic tolerance, educational process, the basic program, competence.

Актуальність проблеми. «Виховання - це процес соціальний у найширшому розумінні. 3 усім складним світом навколишньої дійсності дитина входить у безкінечне число відносин, які незмінно розвиваються, переплітаються з іншими відносинами, ускладнюється моральним і фізичним зростанням самої дитини. Спрямувати цей розвиток і керувати ним - завдання вихователя» [ 3 , с. 24].

В освітній програмі «Я у Світі», якою послуговуються сучасні дошкільні навчальні заклади України, чільне місце у виховному процесі посідає саме педагог. Так, базовими якостями дитини старшого дошкільного віку $\epsilon$ самостійність, працелюбність, людяність, розсудливість, справедливість, самовладання, самолюбність, спостережливість, відповідальність, креативність. Утім, новітні умови модернізації життя та розширення інформаційного освітнього простору, окрім базових якостей, вимагають формування у зростаючої особистості етнокультурної компетентності, міжетнічної толерантності, оволодіння культурою міжнаціонального спілкування. Сформувати гармонійну особистість 3 вищеозначеними якостями, готову до життєдіяльності у новітньому суспільстві під силу лише педагогу, котрий $є$ толерантним та світогляд якого базується на знаннях полікультурного характеру.

Мета статті - на основі результатів експериментального дослідження визначити рівень готовності сучасних вихователів ДНЗ до виховання міжетнічної толерантності дітей старшого дошкільного віку.

Виклад основного матеріалу. Згадана вище чинна програма ДНЗ України не лише окреслює базові якості дитини старшого дошкільного віку, а й акцентує на компетентностях вихованців у різних сферах знань («Люди», «Культура», «Природа» тощо). О. Глузман, досліджуючи поняття «компетентність», щодо структури особистості, дійшов висновку, що вона передбачає здатність застосовувати набуті знання, вміння ефективно й творчо реалізувати себе у взаємодії 3 іншими людьми (у ситуаціях професійного та соціального характеру), сприяє перетворенню ставлень у цінності $[4$, с. 8]. Педагог, що прагне сформувати компетентну особистість, i сам має розвивати власні особистісні та професійні якості. У цьому контексті актуалізувалися новітні педагогічні дослідження проблеми виховання міжетнічної толерантності дітей старшого дошкільного віку, готовності педагогів до виховання цієї якості та дотичних педагогічних питань.

Так, Л. Гончаренко, О. Дубасенюк, В. Зарицька, К. Крутій, Т. Поштарева, Н. Якса досліджують полікультурну освіченість і компетентність педагогів. 
Г. Васянович, І. Зязюн, А. Кірієнко, А. Мельничук акцентують на гуманістичному складнику педагогічної діяльності, вважаючи головною умовою конструктивної взаємодії учасників педагогічного процесу культивування поваги до особистості, культурну самоідентифікацію індивіда. Процес підготовки майбутніх фахівців без урахування етнопедагогічних принципів не мислять О. Ковальчук, Н. Лисенко, М. Стельмахович.

Загальнолюдські та національні культурні пріоритети перебувають у беззаперечній єдності у виховному просторі, отож підготовку педагогів слід реалізовувати, зважаючи на цю єдність, наголошує І. Бех. Науковець переконаний, що кваліфікований педагог має надати дітям знання про культурну спадщину свого та інших народів, допомогти усвідомити власну причетність до створення цієї спадщини впродовж свого життя, розвивати національну самоідентифікацію дітей, плекати у дітей повагу до інших культур, сприяти розумінню самоцінності та унікальності культурного надбання людства [2, с. 11].

На діалог як ефективну форму взаємодії педагога та дітей задля виховання в них міжетнічної толерантності звертають увагу М. Баяновська, А. Бойко, О. Дубасенюк, Л. Кононко, Ю. Тодорцева.

Зокрема, Л. Кононко переконана, що педагог має пристосовуватися до природи вихованців, виявляти гнучкість, ураховувати індивідуальні можливості кожного, чого можна досягти 3 допомогою активного спостереження [6]. Ю. Тодорцева зазначає, що педагог - це самоактуалізуюча особистість, а характеристиками стилю його спілкування є: емпатія, співпереживання; безумовне позитивне ставлення до вихованців; створення атмосфери довіри, що сприяє гармонізації особистості дитини з іiї власним «Я»; партнерство, об’єднання спільних зусиль, толерантність; діалог, мова довіри; сприйняття дитини такою, якою вона є, здійснення іiі захисту, підтримки, надання свободи [9]. У поліетнічних дитячих колективах діалогічна взаємодія сприяє інформаційному, освітньо-культурному обміну, взаємовпливу і регулюванню відносин, уважає М. Баяновська. Науковець переконана, що педагог-новатор має у своїй поліаспектній діяльності виходити за межі класичних, традиційних моделей спілкування. Педагогічна практика дедалі тісніше пов'язана 3 партнерською діяльністю, міжкультурним діалогом, обміном думками [7, с. 38].

У старшому дошкільному віці відбувається становлення схематичного обрису дитячого світогляду, внутрішніх етичних інстанцій, контролю та регуляції поведінки, виникає нова форма спілкування 3 дорослим позаситуативно-особистісна, котра орієнтує зростаючу особистість на світ соціальних відносин, правил поведінки в суспільстві [1, с. 194-205]. Таким дорослим є передусім педагог, котрий не лише керує освітнім процесом, а й $\epsilon$ партнером для вихованців у спілкуванні, навчанні, грі. На кінець старшого дошкільного віку діти повинні знати основні державні символи, характерні ознаки українців; розуміти, що світ населяють люди різних національностей, зовнішності, культури; усвідомити, що людей цінують першочергово за їх моральні якості; орієнтуватися на моральні стандарти, володіти етичними 
еталонами поведінки й спільної з іншими діяльності; бути «толерантними щодо інакшості, визнавати та поважати схожі і відмінні риси людей, поводитися миролюбно, знати межі соціально схвалюваної, прийнятної й неприйнятної поведінки» [1, с. 258-278]. Усе це засвідчує потребу формування в старшого дошкільника міжетнічної толерантності, етнокультурної компетентності, оскільки ці якості передбачають не лише пасивні знання, а й активне їх застосування у різних життєвих обставинах, взаємодії, комунікації.

Задля виявлення рівня готовності педагогів дошкільних навчальних закладів до проблеми виховання міжетнічної толерантності дітей нами проведено анкетування, яким було охоплено 152 вихователі західноукраїнського регіону, з яких 119 проживають у місті, що становить 78\% від загальної кількості, і 33 особи працюють у ДНЗ у сільській місцевості (22\%).

На запитання: «Чи вважаєте актуальною в сучасних умовах проблему формування міжетнічної толерантності дітей? Чому?» ствердну відповідь отримано від 108 опитаних педагогів, що становить 71\%. Утрималося від відповіді 18 опитаних (12\%). Аналіз анкет, у яких респонденти дали негативну відповідь на наше запитання, дозволив припустити відсутність міжетнічних питань у виховному процесі групи, що пов'язано 3 однорідністю етнічного складу дітей чи ДНЗ, де працюють анкетовані.

На основі аналізу даних анкетування визначено причини посилення уваги до проблеми виховання міжетнічної толерантності дітей старшого дошкільного віку: «наявність представників інокультур у групах дітей дошкільного віку та дошкільних навчальних закладах»; «міграція населення як в Україні, так й у світі загалом»; «низький загальний рівень культури та виховання дітей XXI сторіччя»; «загострення конфліктів на міжетнічній основі внаслідок економічної та політичної кризи, а формування міжетнічної толерантності у дітей здатне попередити конфліктні ситуації»; «усі діти мають рівні права на виховання та навчання незалежно від їх етнічного чи культурного походження»; «саме в дошкільному дитинстві відбувається формування особистості, закладаються знання про основні загальнолюдські цінності, а 3 толерантних дітей виростають толерантні дорослі»; «спостерігаються непорозуміння та конфлікти навіть між дітьми однієї національності»; «сучасні умови життя вимагають від підростаючої особистості знань про представників інокультур задля налагодження міжетнічної взаємодії та уникнення непорозумінь та конфліктних ситуацій».

У контексті вивчення розуміння вихователями ДНЗ завдань формування міжетнічної толерантності у виховному процесі отримано такі результати. Із 152 опитаних утрималися від відповіді 58 осіб (38\%), 94 педагоги (62\%) окреслили низку завдань формування міжетнічної толерантності дітей у ДНЗ. Однак із них 18 педагогів (12\%) відповіли, що не вважають актуальною проблему формування міжетнічної толерантності. Основною причиною їхнього твердження стала відсутність представників інокультур чи дітей іноетнічного походження в ДНЗ, де вони працюють. На 
нашу думку, у цьому криється чи не найголовніша суперечність сучасного навчально-виховного процесу в ДНЗ, адже виховувати міжетнічну толерантність слід незалежно від того, відвідують дитячий освітній заклад діти інших національностей чи ні, оскільки полікультурна різноманітність нашої держави загалом не викликає жодних сумнівів.

3-поміж завдань, які, на думку респондентів, слід реалізовувати задля виховання міжетнічної толерантності дітей, виокремлено такі:

1) виховувати повагу, доброзичливе ставлення, дружелюбність до представників інокультур, визнання їх віри, мови, традицій, розвивати вміння спілкуватися з ними (26 педагогів, що становить 17\%);

2) збагатити уявлення про загальнолюдські цінності, культуру поведінки, формувати відносини в дитячому колективі на принципах поваги один до одного, взаєморозуміння, злагоди, доброзичливості, ввічливості, милосердя (24 педагога - 15\%);

3) сформувати у дітей власну етнічну приналежність, зокрема любов до власних національних традицій i звичаїв, а також про полікультурне різноманіття світу, культурну спадщину інших народів, особливості їх звичаїв, традицій, мови, релігії (16 педагогів, що становить 10\%);

4) частина педагогів (7\% - 10 анкетованих) уважають, що в процесі формування міжетнічної толерантності важливо враховувати вікові особливостей дітей; створювати атмосферу поваги до етнокультурних відмінностей між ними; уникати категоричності у власних висловлюваннях; спонукати дошкільників налагоджувати стосунки 3 іншими на основі християнської заповіді «Люби ближнього свого, як самого себе»; розвивати їх духовно.

3'ясування змісту діяльності вихователя 3 формування міжетнічної толерантності дітей, дозволило визначити пріоритети в педагогічній роботі 3 розв’язання окресленої проблеми. Опрацьовані дані анкетування висвітлено в таблиці 1.

Таблиия 1

Зміст діяльності вихователя $з$ формування міжетнічної толерантності дітей (за результатами анкетування вихователів ДНЗ)

\begin{tabular}{|l|c|c|}
\hline \multicolumn{1}{|c|}{ Аспекти педагогічної діяльності } & $\begin{array}{c}\text { Абсолютний } \\
\text { показник }\end{array}$ & $\%$ \\
\hline створення атмосфери поваги до етнокультурних відмінностей людей & 118 & $77,6 \%$ \\
\hline оволодіння знаннями про загальнолюдські цінності & 84 & $55,2 \%$ \\
\hline вивчення рівня толерантності дітей & 66 & $43,4 \%$ \\
\hline вивчення вихованців - носіїв етнокультури & 52 & $34,2 \%$ \\
\hline $\begin{array}{l}\text { розуміння полінаціональної та полікультурної ідентичності своїх } \\
\text { вихованців }\end{array}$ & 51 & $33,5 \%$ \\
\hline урахування вікових особливостей дітей & 50 & $32,8 \%$ \\
\hline дослідження психологічного клімату в колективі & 42 & $27,6 \%$ \\
\hline уникнення категоричності у власних судженнях & 28 & $18,4 \%$ \\
\hline аналіз власних упереджень і стереотипів та їх позбавлення & 15 & $9,8 \%$ \\
\hline
\end{tabular}


Отже, першорядним завданням вихователя у його педагогічній діяльності в руслі окресленої проблеми є створення атмосфери поваги до етнокультурних цінностей людей різних народів. Саме такий підхід уможливить формування міжетнічної толерантності як стійкої якості зростаючої особистості.

На запитання «Які форми та методи доцільно використовувати в роботі 3 ознайомлення дітей 3 цінностями та культурою інших народів» респонденти могли обирати кілька варіантів відповіді. Результати опрацьованих даних анкетування подано в таблиці 2.

Таблиия 2

Форми та методи ознайомлення старших дошкільників 3 культурою свого та інших народів

\begin{tabular}{|l|c|c|}
\hline \multicolumn{1}{|c|}{ Варіанти відповідей } & $\begin{array}{c}\text { Абсолютний } \\
\text { показник }\end{array}$ & $\%$ \\
\hline бесіда & 125 & $82,2 \%$ \\
\hline народні ігри різних народів світу & 117 & $76,9 \%$ \\
\hline читання й аналіз дитячої української та зарубіжної літератури & 96 & $63 \%$ \\
\hline порівняльний аналіз звичаїв, традицій, способу життя, побуту & 91 & $59,8 \%$ \\
\hline пояснення & 68 & $44,7 \%$ \\
\hline дитячі свята & 66 & $43,4 \%$ \\
\hline тематичні ігри різних національних культур & 62 & $40,7 \%$ \\
\hline психологічні тренінги & 17 & $11 \%$ \\
\hline творчі самостійні завдання & 17 & $11 \%$ \\
\hline
\end{tabular}

Отже, на думку педагогів, найбільш доцільними у процесі виховання міжетнічної толерантності дітей $\epsilon$ бесіда (82,2 \%), використання народних ігор різних народів світу $(76,9 \%)$, читання й аналіз дитячої української та зарубіжної літератури (63\%), застосування порівняльного аналізу звичаїв, традицій, способу життя, побуту (59,8 \%). Менш ефективними визнано пояснення (44,7 \%), дитячі свята (43,4 \%), тематичні ігри різних культур (40,7 \%).

Однак, такі форми та методи, як психологічні тренінги (11\%) та творчі самостійні завдання (11\%), як засвідчили дані експериментального дослідження, не користуються популярністю серед сучасних вихователів.

На запитання «Чи потрібно фіксувати у планах виховної роботи ДНЗ цілі, завдання, спрямовані на формування міжетнічної толерантності і культури міжнаціонального спілкування дітей?» відповідь «так, завжди» отримано від 41 респондента, що становить 27\%; «так, інколи» - 96 опитаних (63\%).

Щодо вивчення можливих труднощів педагогів 3 формування міжетнічної толерантності старших дошкільників, то 84 особи вказують на відсутність науково-методичного забезпечення 3 означеної проблеми $(55,2 \%)$. Одним із чинників, що заважають педагогам реалізувати процес формування міжетнічної толерантності дітей, $\epsilon$, за їх думкою, недостатня кількість часу, про яку вказало в анкеті 47 респондентів, що становить $31 \%$. Недостатньо компетентними в окресленій галузі знань себе вважають 38 опитаних (25\%). Менш значущими перешкодами, за результатами анкетування, $є$ відсутність інтересу до проблеми (5,9\% - 9 осіб ). 
Запитуючи в анкетах «У яких формах ви б прийняли допомогу щодо організації роботи з формування міжетнічної толерантності дошкільників?», отримано результати, які подано у таблиці 3.

Таблиия 3

Форми допомоги вихователям у розв'язанні проблеми виховання міжетнічної толерантності старших дошкільників

\begin{tabular}{|l|c|c|}
\hline \multicolumn{1}{|c|}{ Варіанти відповідей } & $\begin{array}{c}\text { Абсолютний } \\
\text { показник }\end{array}$ & $\%$ \\
\hline $\begin{array}{l}\text { лекції та тренінги на курсах підвищення кваліфікації для } \\
\text { педагогів ДН3 }\end{array}$ & 82 & $53,9 \%$ \\
\hline відвідування майстер-класів & 75 & $49,3 \%$ \\
\hline вивчення педагогічних досліджень та кращого педагогічного досвіду & 53 & $34,8 \%$ \\
\hline організація творчих проблемних груп у ДН3 & 26 & $17 \%$ \\
\hline утрималися від відповіді & 2 & $1,3 \%$ \\
\hline
\end{tabular}

Із таблиці зрозуміло, що опитані респонденти бажають отримати допомогу з проблеми виховання міжетнічної толерантності дошкільників у вигляді лекцій і тренінгів на курсах підвищення кваліфікації педагогів ДНЗ (53,9 \%), а також у формі відвідування майстер-класів (49,3 \%). Вивченню педагогічних досліджень і кращого педагогічного досвіду щодо розв'яязання проблеми надало перевагу 53 опитаних педагога (34,8 \%). Найменш привабливими для респондентів $є$ організація творчих проблемних груп у ДНЗ (17\%). Двоє педагогів з усіх опитаних утрималися від відповіді на питання.

У наступних питаннях анкетування педагоги оцінювали рівень знань сучасних старших дошкільників про свою країну, мову, культуру, побут, звичаї, культуру народів, що проживають в Україні. Опрацювання результатів дозволило нам скласти порівняльний аналіз, який відображено на рисунку 1.

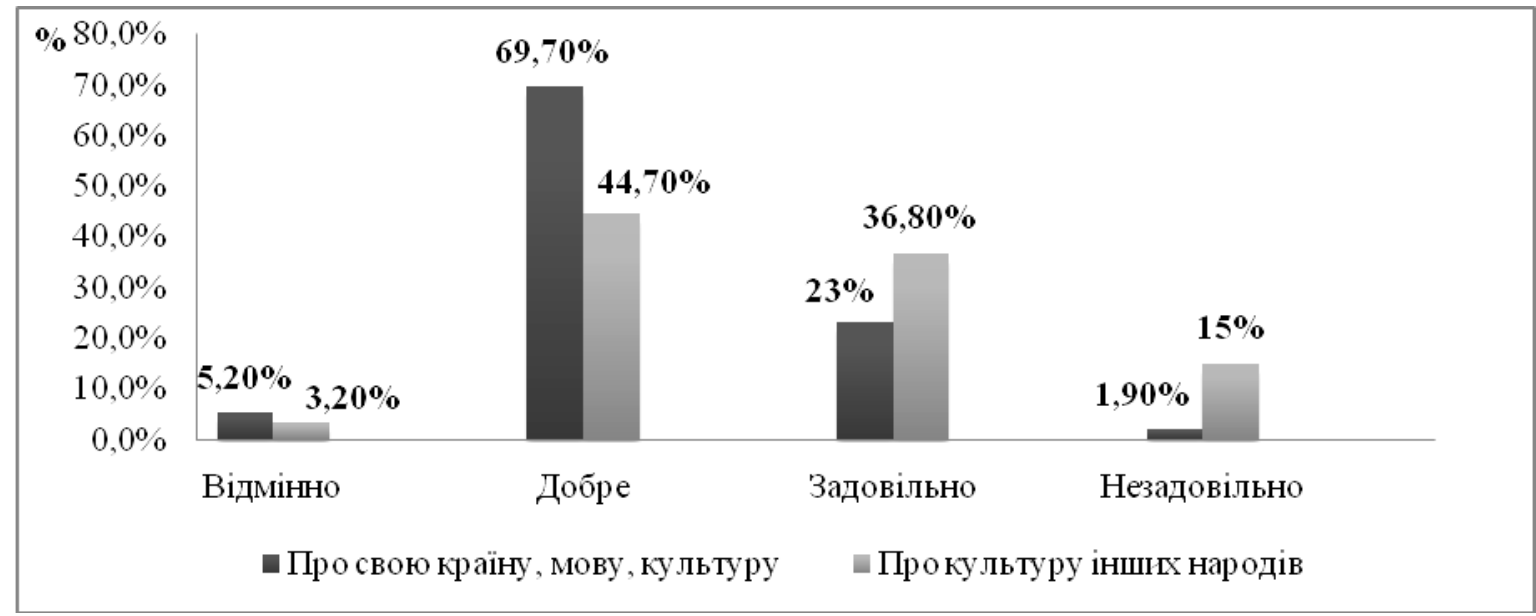

Рис. 1. Порівняльний аналіз рівня знань старших дошкільників про культуру свого та інших народів, що проживають в Україні 
Як бачимо, педагоги вважають рівень знань дітей про культуру свого народу загалом вищим, ніж про культуру інших народів. Проте регулярні спостереження за дітьми, бесіди, дають підстави вважати оцінку педагогів дещо оптимістичною в порівнянні з реальним станом речей.

Висновки. Проведене анкетування дозволило нам зробити висновок, що готовність педагогів до формування міжетнічної толерантності не знаходиться на належному рівні. Опитані фахівці впевнені в актуальності проблеми виховання міжетнічної толерантності старших дошкільників, однак нечітко уявляють шляхи іiі практичного розв'язання. Ретельне вивчення освітньої програми «Я у Світі», новітніх педагогічних досліджень дозволяє зрозуміти весь обсяг відповідальності, яку несе педагог у освітньому процесі. У контексті окресленої проблеми акцентуємо на потребі якісної підготовки вихователів до роботи в сучасних ДНЗ на основі діалогу, толерантності, полікультурності у вищих педагогічних навчальних закладах. Зокрема, Ю. Тодорцева визначає такі шляхи долучення педагогів до реалізації завдань відповідно до умов толерантного освітнього процесу: психолого-педагогічні тренінги; семінари, диспути, полікультурні колоквіуми; практикуми, спецкурси; ділові бесіди, форуми, круглі столи; обговорення літератури; розв'язання конкретних педагогічних ситуацій, задач; самоосвіта засобами дистанційного навчання [9, с. 28]. Велике значення має науково-методичне забезпечення, особистісно зорієнтоване навчання, урахування особистісного комунікативного досвіду, організація самостійної пізнавальної діяльності, розробка навчальних програм, посібників, методичних інструктивних матеріалів (О. Дубасенюк) [5]. А. Бойко вважає, що ставлення дітей до навколишньої дійсності детерміновано саме відносинами «педагогвихованець» [3, с. 14]. Ураховуючи цю взаємозалежність необхідно планувати підготовку фахівців, що працюватимуть у дошкільних навчальних закладах України, приділяючи особливу увагу реалізації новітніх завдань відповідно до умов толерантного полікультурного освітнього простору.

\section{Література}

1. Базова програма розвитку дитини дошкільного віку «Я у Світі» / наук. ред. та упоряд. О. Л. Кононко; [2-е вид., випр.]. - К. : Світич, 2008. - 403 с.

2. Бех І. Д. Виховання особистості: Особистісно-орієнтований підхід: теоретикотехнологічні засади: [монографія] / І. Д. Бех. - К. : Либідь, 2003. - Кн. 1. - 280 с.

3. Бойко А. М. Оновлена парадигма виховання: шляхи реалізації (підготовка вчителя до формування виховуючих відносин 3 учнями) : [навч.-метод. посіб.] / А. М. Бойко. - К. : ІЗМН, 1996. -232 с.

4. Глузман О. В. Базові компетентності: їхня сутність та значення у життєвому успіху особистості / О. В. Глузман // Гуманітарні науки : [науково-практичний журнал]. 2009. - №1. - C. 6-15.

5. Дубасенюк О. А. Підготовка майбутніх учителів до толерантної взаємодії в умовах полікультурного середовища / О.А. Дубасенюк // Вісник Житомирського державного університету імені Івана Франка. - Житомир, 2007. - Випуск 35. - С. $62-65$.

6. Кононко О. Л. Проблема толерантності у контексті особистісно-орієнтованої моделі спілкування / О. Л. Кононко // Педагогіка толерантності. - 1998. - № 1. - С. 5-10. 
7. Матеріали міжнародної науково-практичної конференції «Міжкультурний діалог у сучасній освіті», 11 листопада 2008 р. - К. : Видавець СПД Цудзинович. - Т.І., 2009. $-96 \mathrm{c}$.

8. Поштарева Т. В. Формирование этнокультурной компетентности Т. В. Поштарева // Педагогика. - 2005. - № 3. - С. 35-42.

9. Тодорцева Ю. В. Педагогіка толерантності: [методичні рекомендації] / Ю. В. Тодорцева. - Одеса : СВД Черкасов М. П., 2004. - 90 с.

10. Якса Н. В. Толерантність в системі ціннісно-цільових пріоритетів педагогічної освіти: полікультурний аспект / Н.В.Якса // Вісник Житомирського державного університету імені Івана Франка. - Житомир, 2007. - Випуск 34. - С. 102-105.

Стаття надійшла до редакції 25.05.2012 p.

\section{МОДЕЛЬ ПІДГОТОВКИ МАЙБУТНІХ УЧИТЕЛІВ ТЕХНОЛОГІЙ ДО ВИКОРИСТАННЯ КОМП'ЮТЕРНОЇ ТЕХНІКИ У ПРОЦЕСІ ВИВЧЕННЯ ФАХОВИХ ДИСЦИПЛІН}

\footnotetext{
Терещенко С. П. Модель підготовки майбутніх учителів технологій до використання комп 'ютерної техніки у прочесі вивчення фахових дисииплін.

У статті розглянуто проблему використання комп'ютерної техніки майбутніми вчителями технологій у прочесі вивчення фахових дисциплін, визначено модель підготовки майбутніх учителів технологій до використання комп'ютерної техніки.

Ключові слова: комп 'ютерна техніка, модель підготовки майбутніх учителів технологій.

Терещенко С.П. Модель подготовки будущих учителей технологии к использованию компьютерной техники в процессе изучения специального дисииплин.

В статье рассмотрена проблема использования компьютерной техники будущими учителями технологии в процессе изучения специильных дисциплин, определена модель подготовки будущих учителей технологии к использованию компьютерной техники.

Ключевые слова: компьютерная техника, модель подготовки будущих учителей технологии.

Tereshchenko S. Model of training future teachers of technologies to using the computer technics in the process of studing professional disciplines.

The article deals with the problem of using the computer technics by the future teachers of technologies in the process of studying of specialized disciplines, it is defined the model of training future teachers of technologies to using the computer technics.

Key words: computer technics, model of training future teachers of technologies.
}

Актуальність дослідження. Підготовка педагогічних кадрів у сфері технологічної освіти в нашій країні отримала широке розповсюдження: майже кожен освітній заклад потребує високоосвічених фахівців цієї кваліфікації. Сьогодні актуальним є питання підвищення рівня освіченості вчителів технологій, у цьому напрямі ведуться активні пошуки: розробляються нові кваліфікаційні характеристики фахівців, визначаються професійні якості особистості вчителя, удосконалюються навчальні плани i програми, готуються нові підручники та навчальні посібники. Вища школа сьогодні, насамперед - педагогічна, орієнтується у своєму розвитку на якісну 